\title{
A CASE OF LYMPHOGRANULOMA VENEREUM IN WOMAN
}

\author{
Eun-Kyu Jo, MD¹, Jae-Yeon Jang, MD¹, Sl-Ah Choi, MD¹, Yun-Sook Kim, MD¹, Dong-Han Bae, MD', \\ Hwan-Jun Choi, MD2 , Ji-Hye Lee, $\mathrm{MD}^{3}$ \\ Departments of ${ }^{1}$ Obstetrics and Gynecology, ${ }^{2}$ Plastic Surgery, ${ }^{3}$ Pathology, Soonchunhyang University Cheonan Hospital, Soonchunhyang University College of \\ Medicine, Cheonan, Korea
}

Lymphogranuloma venereum (LGV) is a rare sexually transmitted disease caused by chlamydia trachomatis serotypes L1-L3. The peak incidence occurs in persons 29 to 47 years old, and men are six times more likely than women to manifest clinical infection. The disease clinically manifests in three stages: a primary lesion consisting of a superficial ulcer or erosion, a secondary stage with prominent lymphadenopathy and a later stage with disease manifestations such as fibrosis, fistula, and anorectal strictures. The diagnosis of LGV is based on clinical suspicion, epidemiologic information, and the exclusion of other causes of inguinal lymphadenopathy. Diagnosis of LGV may be difficult. Patients with a clinical syndrome consistent with LGV, including genital ulcer with lymphadenopathy, should be treated for LGV. Recently we have experienced a case of LGV in 44-years-old women with inguinal bubo and sclerosing fibrous skin. We treated her with doxycycline and advancement flap.

Keywords: Lymphogranuloma venereum; Chlamydia trachomatis

성병림프육아종은 클라미디아 트라코마티스 혈청형 L1-3가 원인이 되는 드문 성전파성 질환이다. 클라미디아 트라코마티스의 혈청형 A-K 는 주로 눈 점막 등에 감염이 되고 덜 침습적이나, 혈청형 L1-3는 매우 침습적이며 주로 사람의 림프절에 감염된다[1]. 선진국에서는 드물게 보 고되고 있으나, 아프리카, 동남아시아, 남아메리카 지역의 동성연애자에 서 증가하는 추세이다. 이 질환의 임상 증상은 세 단계로 나타나는데 일 차 병변은 얕은 궤양 또는 미란, 이차 병변은 두드러진 림프절병, 세 번 째 단계의 병변은 섬유화, 림프 부종, 치루형성 등을 포함한다[2,3]. 진단 은 임상증상과 역학적 정보, 그리고 림프절병이나 외음부 궤양의 원인 이 되는 다른 질환을 배제하는 것에 기초하며, 질환이 생긴 림프절의 생 검과 혈청학적 검사를 종합하여 진단할 수 있으나, 임상적 진단의 정확 도는 20\% 미만이다[4]. 성병림프육아종을 진단하는 것은 어렵지만, 감 염자와의 성적 접촉, 외음부 궤양, 치루 또는 가래톳이 있는 환자는 어 떤 경우라도 의심해 봐야 한다[5]. 성병림프육아종에 특이적인 진단적 검사 결과가 없는 경우에도 림프절병과 동반된 직장결장염이나 외음부 궤양을 포함하는 임상적 증후군이 나타나는 환자는 성병림프육아종에 근거하여 치료 받아야 한다[6].

저자들은 44세 여성에서 2년 전에 처음 증상이 있었으나, 치료하지 않고 있다가 서혜부 림프절비대 및 피부로의 농양 샛길을 형성하고, 피 부 섬유화와 육아조직을 형성하여 항생제 사용과 성형외과와의 협진을 통해 병변부위의 광범위 절제와 전진피판술을 통해 치료한 드문 예를 경험하였기에 간단한 문헌 고찰과 함께 보고하는 바이다.

\section{증 례}

환 자: 신 0 숙, 44세

산과력: $1-0-0-1$

월경력: 14 세에 초경을 시작하여 28일 주기로 규칙적이었고, 기간은 7 일이었으며, 양은 중등도였고 월경통은 없었다.

주소 및 현병력: 환자는 내원 2년 전부터 서혜부에 촉진되는 종괴 및 소 양감, 농양 형성, 농양상의 분비물 있었으나 치료받고 있지 않던 분으로 증상 악화되며, 양측 서혜부가 핫도그 모양으로 붓고 피부가 검붉게 변 하고 감각도 둔해지며, 농이 검은 피부 여기저기에서 자연 배출되는 증 세로 정확한 진단과 치료 위해 본원 외래 방문하였다.

Received: 2011. 5.30. Accepted: 2011. 7. 4.

Corresponding author: Yun-Sook Kim, MD

Department of Obstetrics and Gynecology, Soonchunhyang University Cheonan Hospital, 23-20 Bongmyeong-dong, Cheonan 330-721, Korea

Tel: +82-41-570-2150 Fax: +82-41-571-7887

E-mail:drsook@schmc.ac.kr

This is an Open Access article distributed under the terms of the Creative Common Attribution Non-Commercial License (http://creativecommons.org/licenses/ by-nc/3.0/) which permits unrestricted non-commercial use, distribution, and reproduction in any medium, provided the original work is properly cited.

Copyright $\odot$ 2011. Korean Society of Obstetrics and Gynecology 


\section{KOREAN JOURNAL OF OBSTETRICS \& GYNECOLOGY}

Eun-Kyu Jo, et al. Lymphogranuloma venereum in woman
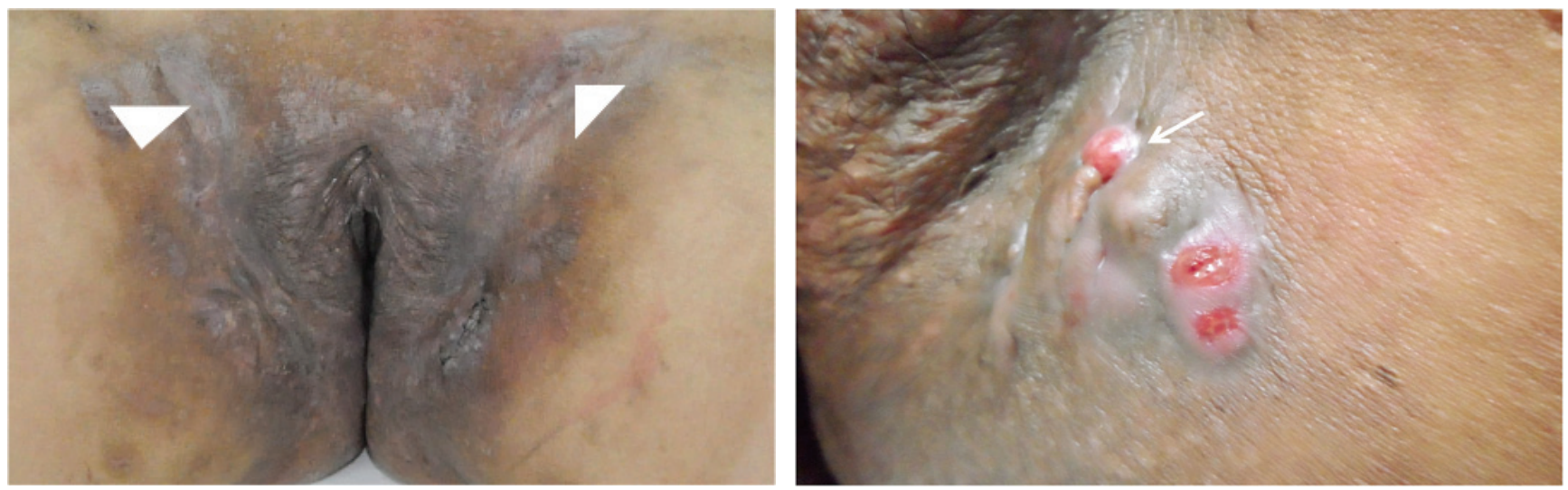

Fig. 1. Gross finding showed both inguinal bubo (arrowhead) and multiple granulation tissues, fistula, and abscess formations (arrow).

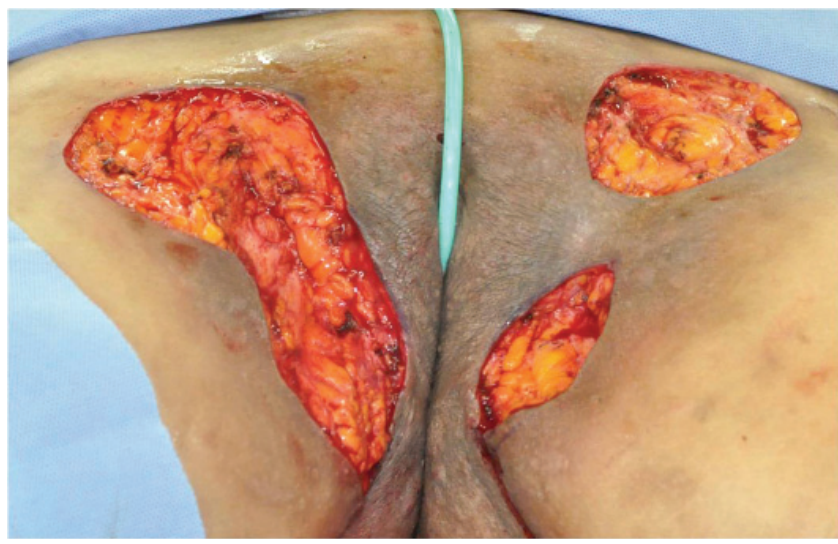

Fig. 2. Granulation tissues were wide excised and advancement skin graft was done by plastic surgeon.

과거력: 환자는 내원 10년 전 좌측 난소 난관 농양으로 산부인과 입원 하여 항생제 치료한 적 있으며, 당뇨, 자가면역질환 등의 내과적 과거력, 마약 등의 약물 복용력 전혀 없었다. 동성연애나 항문성교 등의 과거력 없었다.

가족력과 수술력: 내원 20년 전둔위태위로 제왕절개술 시행받았으며, 2 년 전 이혼 후 현재 부모님과 함께 살고 있었으며, 특별한 직업 없었고, 말이 약간 어눌하고 지능이 다소 떨어져 보호 1종 진단받은 상태였다. 신체검사 소견: 내원 당시 신체 검진에서 혈압 $120 / 80 \mathrm{~mm} \mathrm{Hg}$, 맥박 84 회/분, 호흡수 20 회/분, 체온 $36.7^{\circ} \mathrm{C}$ 이었고 의식은 명료하였다. 흉 부 소견에서 호흡음은 깨꼿하였고, 심박동은 규칙적이었으며, 심잡음은 들리지 않았으며, 질경검사에서 자궁경부와 질에 이상 소견 보이지 않 았다. 요도와 항문에 이상 소견 없었고, 변비나 뒤무직 등의 증세는 없 었다. 좌측 서혜부에 $70 \times 40 \mathrm{~mm}, 60 \times 30 \mathrm{~mm}$, 우측 서혜부에 $30 \times 30$ $\mathrm{mm}, 20 \times 30 \mathrm{~mm}$ 크기의 압통이 동반된 고정된 종괴소견 보이며 종괴 를 누르면 농이 배출되었고, 림프절에서 피부로 연결되는 샛길이 관찰 되었고, 샛길 통해 농이 배출되고 있었다. 양측 서혜부에서 대음순에 걸 쳐 전반적으로 피부색이 검게 변해 있었고, 감각이 둔화되어 있었으며 다발성의 종괴와 종괴에서 분비되는 농이 보였다(Fig. 1).

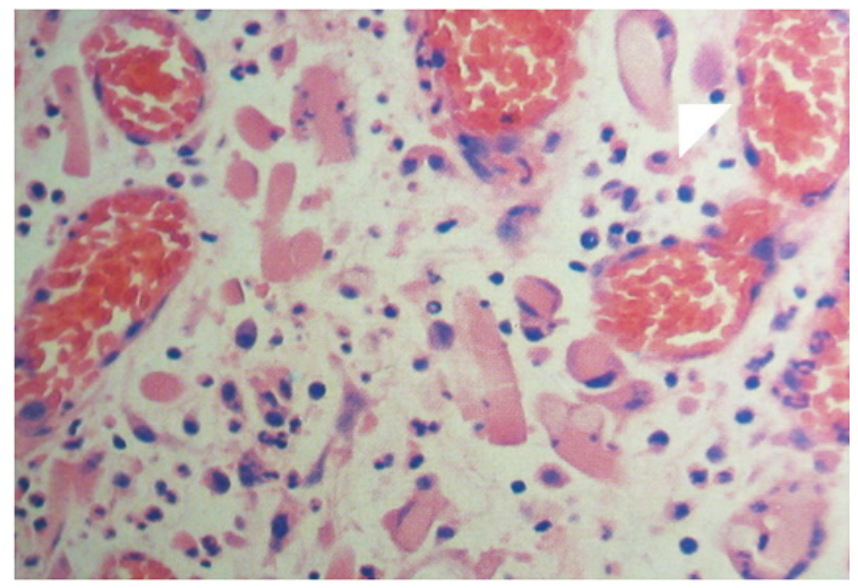

Fig. 3. Histologic appearance showing epithelial granuloma with giant cells (arrowhead), with many large and greatly dilated thin-walled blood vessels $(H \& E, \times 200)$.

검사실검사 소견: 입원 당시 혈액검사에서 혈색소 $14.1 \mathrm{~g} / \mathrm{mL}$, 적 혈구 용적 $41.4 \%$ 였고, 백혈구, 혈소판 수치는 정상이었다. B형간염 항원검사, 항hepatitis C virus $(\mathrm{HCV})$ 검사, 혈액응고검사, 신기능검 사, 간기능검사, 그리고 요검사에서 이상 소견 없었다. C-반응성 단 백질 수치는 $1.18 \mathrm{mg} / \mathrm{L}$ (참고치, $0.01-2.61 \mathrm{mg} / \mathrm{dL}$ ), 매독 선별검 사, human immunodeficiency virus (HIV) 항원, 항체검사는 음성이었 다. 자궁경부 액상세포검사에서 이상 소견 없었으며, 인유두종바이러 스(human papilloma virus)검사에서도 음성소견 보였다. 농이 배출되 는 병변부위를 면봉으로 채취하여 시행한 중합효소연쇄반응검사에서 Neisseria gonorrhea, Ureaplasma urealyticum, Mycoplasma hominis, Herpes simplex, Trichomonas vaginalis에는 음성을 보였고, Chlamydia trachomatis에만 양성 소견을 보였다. Haemophilus ducreyi 배양 검사에 서 음성 소견 보였다. Chlamydia trachomatis 표현형 L1, L2, L3를 알기 위한 추가검사는 시행하지 않았다.

입원 및 치료 경과: 입원하여 sulfamethoxazole $400 \mathrm{mg} /$ day, gentamicin $80 \mathrm{mg} /$ day, ceftriaxone $2 \mathrm{~g} /$ day, doxycycline $200 \mathrm{mg} /$ day를 총 3주간 


\title{
KOREAN JOURNAL OF OBSTETRICS \& GYNECOLOGY
}

\author{
KJOG Vol. 54, No. 9, 2011
}

사용하였다. 항생제 치료 후 외음부 농양 및 분비물은 완전히 호전되었 다. 섬유화된 서혜부 피부는 성형외과와 협의하여 광범위 절제 및 옆의 정상 피판을 절제한 부위로 옮겨 좀 더 보강해 주는 전진피판술 시행하 였다(Fig. 2). 치료 6개월 후 환자는 특별한 증세 없이 지내고 있다.

병리조직학적 소견: 최종 병리에서 거대세포가 있는 육아 조직, 많은 확 장된 얇은 혈관으로 형성된 농양으로 진단되었다(Fig. 3).

\section{고 찰}

성병림프육아종은 클라미디아 트라코마티스 혈청형 L1-3가 원인이 되는 드문 성전파성 질환으로 1 개 또는 그 이상의 외음부 궤양과 구진 발생 후에 생기는 단측성 혹은 양측성의 서혜부 림프절 병변이 특징적 으로 나타난다[1]. 유병률은 29-47세, 도시 거주자, 그리고 사회 경제 적으로 낮은 지위의 인구에서 높으며, 질, 항문, 구강 성교를 통해 모두 감염될 수 있고 임상적인 감염 증상은 남자에서 여자보다 6 배 높게 나 타난다[2-8]. 2010년 연구에 의하면 성기 부위 궤양 중 1기 매독이 약 $35 \%$, 헤르퍼스가 $27 \%$, 연성하감이 $3 \%$ 를 보이고, 성병림프육아종은 드 물어 약 $1 \%$ 를 차지한다고 하였다[9]. 성병림프육아종은 몇몇 열대 지역 에서 높은 발생률을 보이고, 서부 유럽에서는 수십 년 동안 드물게 나 타났지만, 2003년 이후 성병림프육아종의 보고가 연속적으로 증가되었 고, 대부분이 동성과 성관계를 가지는 남성에서 발생했다[7]. 임상 증상 은 환자의 성별, 질환의 감염 경로, 질병의 단계에 따라 3단계로 나누어 진다. 첫 번째 단계는 감염 3-30일의 잠복기 후에 5-8 mm의 무통성 홍반성 구진이나 작은 포진상 궤양이 감염 부위에 나타나며, 일반적으 로 남성에서는 귀두, 음경 꺼풀에 병변이 나타나고, 여성에서는 질 후벽, 음순, 때로는 자궁 경부에서 나타난다. 첫 번째 단계는 일시적이며, 수일 내에 자연 치유되고, 인지되지 못하고 지나가는 경우가 많다. 두 번째 단계에서는 첫 번째 병변이 나타난 지 2-6개월 후에 뚜렷한 림프절 침 범과 혈행성 파종이 나타나며, 림프절염은 종종 8-12주 이내에 자연적 으로 호전된다. 이 단계에서 병변은 서혜부 또는 대퇴부 림프절을 침범 하여 이 림프절 부위 피부에 발진이 생기며, 1-2주 후 림프절은 커지고 합쳐져 단단하고 압통을 동반하며 유동성이 없는 종괴를 형성한다. 이 것은 피부로 파열되며 샛길을 형성하여 농을 배액한다. 약 $1 / 3$ 의 경우 에서만 양측성으로 나타난다. 단측 혹은 양측 서혜부 인대의 림프절이 커지는 '그루브 징후(groove sign)'는 성병림프육아종의 특이적인 증상 이며, 10-20\%에서 나타난다[8,9]. 대부분의 환자는 치료 후 후유증 없 이 호전되지만, 항문주위 림프절 침범이 있던 환자가 치료되지 않은 경 우 일부에서 세 번째 단계로 크론병과 유사한 직장염이 생길 수 있으며, 성병림프육아종 직장염의 초기 증상은 소양감과 분비물이며, 이후 발열 과 항문통, 뒤무직 증상이 생기게 된다[10]. 외음부 병변이 생긴 경우 지 연성 후유증은 매우 드물어 약 $4 \%$ 정도에서 생긴다[11]. 만성적으로 치 료되지 않은 환자에서 피부의 섬유화가 일어나고 림프절을 막아 외음부 와 다리에 림프부종을 일으킬 수도 있다. 상기 환자의 경우 내원 2년 전 에 서혜부의 발진이 시작되었으나 치료를 받지 않고 치유되었다가, 수
주 후에 양측 서혜부 종창과 농 양상의 분비물이 지속되었으나 환자가 경제적으로 매우 어려운 처지가 되어 치료받지 않고 지내던 중 서혜부 분비물 양 많아지고, 압통 심해지며, 피부 감각이 둔해지고 변색이 심해 지는 증상 있어 본원 내원하였다. 환자에서는 첫 번째 단계는 자연적으 로 치유되고, 내원 시에는 두 번째 단계가 제대로 치료되지 않아 양측 서혜부에 통증과 압통이 동반된 고정된 종괴 소견을 보이며 농이 배출 되고, 림프절에서 피부로 연결되는 샛길이 생긴 것으로 보인다.

진단은 임상증상과 역학적 정보, 그리고 림프절병이나 외음부 궤양의 원인이 되는 다른 질환을 배제 하는 것에 기초하며, 질환이 생긴 림프절 의 생검과 혈청학적 검사를 종합하여 진단할 수 있다[12,13]. 과거에는 Frei 항원을 이용한 Frei test를 시행했으나 낮은 특이성으로 더 이상 사 용하지 않는다. 외음부와 림프절 병변을 면봉 채취하거나 흡인한 검체 로 배양, 직접 면역 형광법 또는 핵산 검출법을 이용하여 클라미디아 트 라코마티스 검사를 시행할 수 있다. 또한 합당한 임상적 증상이 있을 때 클라미디아 혈청검사에서 항체가 1:256 이상인 경우와 보체 고정 역가 가 1:64를 넘는 경우 진단의 근거가 될 수 있다[14]. 병변부위 림프절생 검을 시행 할 경우 화농성 육아종성 염증소견 보이며, 괴사부위는 농양 으로 커지고 이것들은 합쳐져 분비강을 형성하게 된다. 그러나 이런 소 견들은 성병림프육아종에 특이적인 것은 아니다[15]. 감별해야 할 질병 으로는 연성하감, 헤르퍼스, 매독, HV 등이 있다. 그 외에도 성병림프 육아종이 C형 간염의 전파를 용이하게 하므로 항상 C형 간염의 가능성 을 염두에 두어야 한다[15]. 상기 환자의 경우 외음부 궤양은 보이지 않 았으며, 반응성 서혜부 림프절염을 유발할 수 있는 감염의 증거 없었고, 혈액검사에서 림프절 비대를 일으킬 수 있는 자가면역 억제 질환의 가 능성은 전혀 없었고, 항 $\mathrm{HCV}$ 는 음성이었다. 환자는 임상적으로 압통이 동반된 서혜부 림프절 비대와 농양 형성 및 농성 분비물이 있었으며, 림 프절과 피부가 연결되는 샛길이 관찰되었다. 병변부위 면봉 채취 후 시 행한 중합효소연쇄반응검사에서 클라미디아 트라코마티스에 양성 소견 을 보였다. 클라미디아 트라코마티스 표현형 L1, L2, L3를 알기 위한 추 가 중합효소 연쇄 반응 검사는 시행하지 않았다. 병변부위 부분 절제 조 직검사를 시행한 결과 육아조직 소견 있었으며, 광범위 절제 후 조직검 사에서는 육아조직 및 농양 형성 소견 있었다. 임상 증상 및 신체 진찰 소견과 조직검사 소견, 그리고 병변 부위의 중합효소연쇄 반응검사에서 성병림프육아종에 합당하였다.

그러나 성병림프육아종의 임상적 진단의 정확도는 $20 \%$ 미만으로 감 염자와의 성적 접촉, 외음부 궤양, 치루 또는 가래톳이 있는 환자는 어 떤 경우라도 의심해 봐야 하며, 성병림프육아종에 특이적인 진단적 검 사 결과가 없는 경우에도 림프절병과 동반된 직장결장염이나 외음부 궤 양을 포함하는 임상적 증후군이 나타나는 환자는 성병림프육아종에 근 거하여 치료 받아야 한다[11,14]. 치료는 테트라사이클린 $500 \mathrm{mg}$ 을 하 루 4회씩 14일간 투여하거나 독시사이클린 $100 \mathrm{mg}$ 하루 2회 14일간 사용하며, 임산부에서는 테트라사이클린이 금기이므로 에리스로마이신 $500 \mathrm{mg}$ 하루 4회 14 일간 사용할 수 있다. 더 진행된 만성적인 병변의 경우 약 21일간의 항생제 사용이 필요하다. 농은 배출시켜야 하며, 섬 유화된 피부는 광범위 절제로 주위의 정상 피부로 덮어 주어야 하며, 항 


\section{KOREAN JOURNAL OF OBSTETRICS \& GYNECOLOGY}

Eun-Kyu Jo, et al. Lymphogranuloma venereum in woman

문-질의 샛길이 생겼거나 장 폐색이 생긴 경우 수술적인 교정이 필요하 다[15]. 치료 후 클라미디아 검사가 음성이고, 임상적으로 증상이 없어질 때까지 추적관찰을 해야 하며 콘돔 같은 차단 피임법을 통해 예방할 수 있다. 상기 환자는 만성적으로 진행된 병변으로 설파메독사졸, 젠티마이 신, 독시사이클린을 3주간 사용하였고, 경화되어 변색된 피부는 성형외과 와 협의하여 광범위 절제 및 전진피판술 시행 받았다. 6 개월까지 추적관 찰에서 증상 없었고, 추가 혈액검사와 균검사는 시행하지 않았다. 저자들 은 44세 여성에서 서혜부 림프절비대 및 농양을 동반한 성병림프육아종 을 진단하여 치료하였기에 간단한 문헌 고찰과 함께 보고하는 바이다.

\section{References}

1. Mabey D, Peeling RW. Lymphogranuloma venereum. Sex Transm Infect 2002;78:90-2.

2. Centers for Disease Control and Prevention (CDC). Lymphogranuloma venereum among men who have sex with men-Netherlands, 2003-2004. MMWR Morb Mortal Wkly Rep 2004;53:985-8.

3. Nieuwenhuis RF, Ossewaarde JM, Götz HM, Dees J, Thio HB, Thomeer MG, et al. Resurgence of lymphogranuloma venereum in Western Europe: an outbreak of Chlamydia trachomatis serovar 12 proctitis in The Netherlands among men who have sex with men. Clin Infect Dis 2004;39:996-1003.

4. Herida M, Sednaoui P, Couturier E, Neau D, Clerc M, Scieux C, et al. Rectal lymphogranuloma venereum, France. Emerg Infect Dis 2005;11:505-6.

5. Blank S, Schillinger JA, Harbatkin D. Lymphogranuloma vene- reum in the industrialised world. Lancet 2005;365:1607-8.

6. Meyer T, Arndt R, von Krosigk A, Plettenberg A. Repeated detection of lymphogranuloma venereum caused by Chlamydia trachomatis L2 in homosexual men in Hamburg. Sex Transm Infect 2005;81:91-2.

7. Kropp RY, Wong T; Canadian LGV Working Group. Emergence of lymphogranuloma venereum in Canada. CMAJ 2005;172:1674-6.

8. French $P$, Ison $C A$, Macdonald N. Lymphogranuloma venereum in the United Kingdom. Sex Transm Infect 2005;81:97-8.

9. Workowski KA, Berman S; Centers for Disease Control and Prevention (CDC). Sexually transmitted diseases treatment guidelines, 2010. MMWR Recomm Rep 2010;59:1-110.

10. Watson DJ, Parker AJ, Macleod TI. Lymphogranuloma venereum of the tonsil. J Laryngol Otol 1990;104:331-2.

11. Thorsteinsson SB, Musher DM, Min KW, Gyorkey F. Lymphogranuloma venereum. A cause of cervical lymphadenopathy. JAMA 1976;235:1882.

12. Dangor $Y$, Ballard RC, da LEF, Fehler G, Miller SD, Koornhof HJ. Accuracy of clinical diagnosis of genital ulcer disease. Sex Transm Dis 1990;17:184-9.

13. Drew 0 , Smith $Y$, Jackie $S$. Sexually transmitted infections. Medicine 2007;35:410-2.

14. Marchand C, Granier F, Cetre JC, Brutzkus A, Perrot H. Anal lymphogranuloma venereum with erythema nodosa. Apropos of a case. Ann Dermatol Venereol 1987;114:65-9.

15. Schachter J, Osoba AO. Lymphogranuloma venereum. Br Med Bull 1983;39:151-4.

\section{성병림프육아종 1예}

\section{순천향대학교 의과대학 '산부인과학교실, ${ }^{2}$ 성형외과학교실, ${ }^{3}$ 병리학교실}

조은규 ${ }^{1}$, 장재연 ${ }^{1}$ 최슬아', 김윤숙, 배동한 ${ }^{1}$ 최환준 ${ }^{2}$, 이지혜 ${ }^{3}$

성병림프육아종은 클라미디아 혈청형 L1-3가 원인이 되는 드문 성전파성 질환이다. 29-47세, 도시 거주자, 사회 경제적으로 낮은 지위의 인구에서 높으며, 임상적인 감염은 남자에서 여자보다 6배 높게 나타난다. 임상 증상은 세 단계로 나타나는데 일차 병변은 얕은 궤양 또는 미란, 이차 병변은 두드러진 림프절병변, 삼차 병변은 섬유화, 림프 부종, 치루 형성 등을 포함한다. 진단은 임상증상과 역학적 정보, 그리 고 림프절이나 외음부 궤양의 원인이 되는 다른 질환을 배제하는 것에 기초하며, 질환이 생긴 림프절의 생검과 혈청학적 검사를 종합하여 진단할 수 있다. 그러나 진단이 매우 어렵기 때문에 림프절병과 동반된 외음부 궤양을 포함하는 임상적 증후군이 나타나는 환자는 성병림 프육아종에 근거하여 치료 받아야 한다. 최근 저자들은 44세 여성에서 서혜부 림프절비대 및 외음부 궤양과 피부 샛길을 형성한 농양을 동반한 성병림프육아종을 진단하여 독시사이클린과 전진피판술을 이용하여 치료하였기에 간단한 문헌 고찰과 함께 보고하는 바이다.

중심단어: 성병림프육아종, 클라미디아 트라코마티스 